\title{
Incidence of metabolic disorders and reproductive performance following a short (35-d) or conventional (60-d) dry period management in commercial Holstein herds
}

\author{
D. E. Santschi, ${ }^{\star} \dagger^{1,2}$ D. M. Lefebvre, $\neq$ R. I. Cue, $\S$ C. L. Girard, ${ }^{\star}$ and D. Pellerin ${ }^{1}$ \\ *Agriculture and Agri-Food Canada, Dairy and Swine Research and Development Centre, Sherbrooke, Quebec, Canada, J1M 1 Z3 \\ †Département de Sciences Animales, Université Laval, Quebec, Canada, G1V 0A6 \\ ¥Valacta, Ste-Anne-de-Bellevue, Quebec, Canada, H9X 3R4 \\ §Department of Animal Science, McGill University, Ste-Anne-de-Bellevue, Quebec, Canada, H9X 3V9
}

\section{ABSTRACT}

A total of 850 Holstein cows from 13 commercial dairy herds were involved in the present study to compare the effects of 2 different dry period (DP) management strategies on health and reproductive parameters. Cows were assigned to either a short (SDP; $35-\mathrm{d}$ ) or a conventional (CDP; 60-d) DP management within each herd, based on previous 305-d milk yield, parity (414 primiparous and 436 multiparous), and estimated calving interval. Cows assigned to CDP were fed a dry cow ration from dry-off until $21 \mathrm{~d}$ prepartum, and were then switched to a precalving ration. Cows assigned to SDP were fed the precalving ration throughout their DP. Rations were specific to each herd. A significant treatment $\times$ parity interaction was found for culling rate. Dry period management did not affect culling rate for second-lactation cows but a significantly higher culling rate occurred in multiparous CDP cows compared with SDP (42.6 vs. $31.6 \% \pm 3.7$ for CDP and SDP, respectively). Management used in the DP did not affect incidence of severe ketosis, displaced abomasum, milk fever, and mastitis, although incidence of these metabolic disorders were lower in second-lactation than third- or greater-lactation cows. The incidence of mild ketosis (evaluated by milk ketone concentration) was lower following SDP, probably as a result of better energy balance. On the other hand, the incidence of retained placenta was higher in multiparous cows assigned to SDP, but the reason for this increase remains unclear. Nevertheless, this did not lead to increased incidence of metritis. Moreover, DP management did not influence reproductive measures, including days in milk at first breeding, number of breedings per conception,

Received July 5, 2010.

Accepted March 30, 2011.

${ }^{1}$ Current address: Valacta, Ste-Anne-de-Bellevue, Quebec, Canada, H9X 3R4

${ }^{2}$ Corresponding author: dsantschi@valacta.com as well as conception rates at first and second services. Regarding days open, overall, all 13 herds were not significantly affected by treatment, but 1 herd clearly showed opposite results to the 12 others. Our results indicate that a short DP management strategy could facilitate transition from one lactation to the next by decreasing the incidence of mild ketosis, with no major negative effects on other health parameters and reproduction. The variation in results observed among herds suggests that other management practices influence the response observed following a short or conventional DP, emphasizing the need for other field studies.

Key words: dairy cow, short dry period management, health, reproduction

\section{INTRODUCTION}

The transition period is generally recognized as the most critical period of the lactation cycle for a dairy cow. The endocrine and physiological changes that accompany parturition and the onset of milk production negatively affect immune function and DMI. As a result of nutrient demand for milk production increasing faster than DMI, cows experience a period of negative energy balance of varying duration and intensity. Early lactation is also a critical time for metabolic disorders, of which most occur during the first 2 wk postpartum (Goff and Horst, 1997). The extent of negative energy balance is related to the incidence and severity of most metabolic disorders, such as ketosis, displaced abomasum, retained placenta, and susceptibility to infections (Grummer et al., 2004). In addition, improved energy balance has been proven to result in greater reproductive efficiency through earlier resumption of ovulatory cycles (Butler, 2005). Early resumption of cycles is important because conception rates increase with successive cycles (reviewed by Butler, 2003). Enhancing nutrient intake seems, therefore, imperative to maximize health and reproduction of periparturient cows.

Shortening the dry period (DP) has been proposed as a method to attenuate the decrease in feed intake 
before calving and improve energy balance around parturition. Although a minimal DP length has been proven to be essential to ensure milk production in the following lactation (Bachman and Schairer, 2003; de Feu et al., 2009; Klusmeyer et al., 2009), decreasing this nonlactating period to 28 to $35 \mathrm{~d}$ was associated with improved energy status in early lactation (Rastani et al., 2005; Pezeshki et al., 2007). A traditional 60-d DP management implies feeding a dry period ration from dry-off until $21 \mathrm{~d}$ prepartum and then a precalving ration until calving. Shorter DP management facilitates transition by decreasing the number of dietary changes; the precalving ration can be fed throughout the DP. Because it is generally known that adaptation to a new diet takes up to 4 wk (as reviewed by Goff and Horst, 1997), decreasing the number and amplitude of dietary changes should decrease the nutritional stress experienced by dairy cows during the periparturient period. Shortening the DP might, therefore, improve ruminal adaptation in early lactation, decrease the incidence of metabolic disorders, and improve reproductive performance. These variables are of considerable importance for dairy producers to make management decisions. However, limited information exists on the effects of DP lengths on health and reproduction because large numbers of animal are needed to get enough statistical power to detect treatment differences.

Coppock et al. (1974) tried to define the optimal length of DP in commercial herds, in a study involving 1,583 cows from 65 herds. Cows were randomly assigned to DP lengths of 20, 30, 40, 50, and $60 \mathrm{~d}$, irrespective of their late lactation yield. Only 38 herds completed the 42-mo trial. In addition, several cows had to be removed from the study because they were dried earlier than the planned DP because of low milk production. Results suggested no effects of DP length on incidences of retained placenta, ketosis, and milk fever. However, their study took place several decades ago, with cows producing less than 7,000 kg of milk per year. More recently, Watters et al. $(2008,2009)$ used 781 cows from 1 herd to determine effects of a 55 - or 34-d DP on health and reproduction. They observed no treatment difference for incidence of ketosis, retained placenta, displaced abomasum, and metritis. However, shorter DP decreased median days until first postpartum ovulation and improved reproductive performance in third- or greater-lactation cows.

The fact that management practices might influence responses to short DP places the emphasis on conducting research on commercial farms, which is seldom done for logistic reasons. The present study was designed to evaluate the effects of DP managements on health and reproductive measures on a large number of animals in commercial settings. To do so, several herds were involved in the study. This study offered an insight into variation, which could occur among herds. However, it was not the purpose of this study to assess why results would differ from one herd to the other. Production and BCS results have been reported elsewhere (Santschi et al., 2011a).

\section{MATERIALS AND METHODS}

All experimental procedures were approved by the Animal Care Committee from Université Laval, Quebec, Canada.

\section{Experimental Procedures}

Description of herds and cows involved was given previously (Santschi et al., 2011a). Briefly, 850 Holstein cows (414 primiparous and 436 multiparous) from 13 commercial dairy herds were used to compare the effects of conventional (CDP; 60-d) and short (SDP; 35d) DP management strategies. Specific details on each herd are provided elsewhere (Santschi et al., 2011b). Herds were comparable to average eastern Canada herds in terms of herd size. Every 2 mo, cows in their sixth or seventh month of gestation within each herd were assigned to 1 of the 2 treatments based on parity (primiparous vs. multiparous), previous 305-d milk yield, and estimated calving interval. Cows in the CDP group were fed a dry-cow ration from dry-off until 21 d before calving, when they switched to a precalving ration, whereas cows in the SDP group received the precalving diet for the whole duration of their DP. All cows were fed the early lactation ration after calving. Rations were specific to each herd.

The method for drying-off was variable but key procedures were similar across herds: cows with low milk production were dried abruptly, whereas high-producing cows were dried over several days, often with single daily milking to decrease production. All producers used dry cow antibiotics at dry-off, and were provided with SNAP Beta-Lactam Tests (Idexx Laboratories, Inc., Westbrook, MN) to detect residues in early lactation milk.

Besides the ration change during the DP, producers were asked to feed and treat all cows as usual, and to report any observations. The study lasted $2 \mathrm{yr}$, from January 2007 until December 2008.

Following each calving, producers were asked to provide information on periparturient events: administration of calcium or other minerals, milk fever, retained placenta, metritis, dystocia, mastitis, size of calf (small, medium, large), as well as any other observation, problem, or treatment. 


\section{Data Collection}

All health and metabolic data were obtained either directly from the producer at each visit or through the veterinary records. Monitoring by veterinarians was variable among herds, according to the producer and the herd's veterinarian routine procedure. Most herds (11 out of 13) were routinely visited once per month by the veterinarian. These visits included pregnancy checks as well as evaluation and treatment of any sick cows. One herd was visited every third week by the veterinarian with similar monitoring, whereas the last herd was visited only in case of emergencies (no pregnancy checks). Researchers visited each herd every other week throughout the $2 \mathrm{yr}$ of the project.

Information on reasons and DIM at culling was obtained from producers and Valacta (Ste-Anne-deBellevue, QC, Canada). Cows were considered as culled if they were not kept in the herd until their next DP. Unintentional culling was defined as a cow leaving the herd for reasons that severely affect or prevent milk production, whereas intentional culling was defined as a productive cow leaving the herd because she no longer met the producer's standards.

To standardize the information obtained from each herd, specific criteria were determined for each metabolic disorder and are described below.

Producers systematically recorded calving difficulty for every calving (no assistance, light assistance, difficult calving, surgery, or non-favorable calf presentation). Calving difficulty was used as a criterion to define dystocia, which corresponds to the definition used by Mee (2008). Calving requiring human intervention (difficult calvings, requiring surgery or accompanied by a non-favorable calf presentation) were classified as dystocia, in opposition to calvings requiring little or no assistance. Although a subjective measure, visual classification of calf size as small, medium, or large was used because it was not possible to measure calf weight at a specific time after birth in all herds over the 2-yr period. It was assumed that large and small cows were evenly distributed among treatments and that the producer's evaluation of calf size would allow comparison between the treatments within each herd and, therefore, provides an estimate of overall treatment effect on calf size. These classifications of calving difficulty and calf size are the standard classification used by the Canadian genetic evaluation system (Jamrozik et al., 2005).

Retained placenta was described as partial or complete failure to remove fetal membranes within $24 \mathrm{~h}$. Fresh cows between 3 and 21 DIM on the day of the visit were tested for ketosis using Keto-Test (Elanco Animal Health, Guelph, ON, Canada) for detection of
BHBA in milk. Milk was collected from one quarter; the Keto-Test strip was dipped in it for $3 \mathrm{~s}$, and the result was measured $60 \mathrm{~s}$ later. Cows were declared non-ketotic if the test showed a result below $100 \mu \mathrm{mol}$ of $\mathrm{BHBA} / \mathrm{L}$; as having mild ketosis at values between 100 and $200 \mu \mathrm{mol}$ of $\mathrm{BHBA} / \mathrm{L}$; and severe ketosis at values at or above $200 \mu \mathrm{mol}$ of BHBA/L, as suggested by the manufacturer. For cows that were tested twice (on 2 consecutive visits), the highest result was kept as indicator of ketosis.

Milk fever was ranked as none (cow showing no clinical signs, whether preventive calcium was administered or not), mild (weak or uncomfortable cow improved after administration of calcium or other minerals), or severe (cow cannot get up). All administered doses of calcium either as a preventive or treatment measure were recorded. Clinical metritis was defined as vaginal discharge of abnormal smell and color within the first 21 DIM, usually accompanied by fever and general illness, and was identified by the producer. Veterinary diagnosis and intervention were the criteria for displaced abomasum. Clinical mastitis was recorded throughout lactation, observed by the producer as abnormal milk requiring treatment. The occurrence of any health problem and medical intervention were recorded throughout the experiment with the help of the veterinarians supervising each herd. Data on breedings per conception as well as DIM at first and last breeding were obtained from Valacta (DHI service provider for eastern Canada). The gestation length was calculated as the number of days between conception (last insemination) and calving. All data collected before culling was kept for analysis, except DIM at last breeding, which was only computed for cows confirmed pregnant before being culled and non-culled cows.

In addition to the previously described data, cows were body condition scored throughout the project and milk and component yields were obtained monthly. Results for these variables have been presented elsewhere (Santschi et al., 2011a).

\section{Statistical Analyses}

Proportions of culled cows were determined using the GLIMMIX procedure of SAS (version 9.2; SAS Institute, 1999) after conversion to binomial distribution. Fixed effects of the model were treatment, parity, block, and herd as well as the treatment $\times$ parity interaction. The term parity referred to primiparous or multiparous at dry-off, whereas block represented the 2-mo assignation period. Reasons for culling and time of culling relative to calving were compared using Proc FREQ. The chi-squared statistic was used to determine difference between treatments. 
The incidence of metabolic disorders was also determined using the GLIMMIX procedure of SAS, with the same model as described above. Incidence of ketosis and milk fever was converted to a binomial distribution for easier analysis. Regarding ketosis, 2 distributions were compared. First, ketotic versus non-ketotic cows (Keto-Test result $<100$ vs. $\geq 100 \mu \mathrm{mol}$ of BHBA/L). The second comparison was severe ketosis versus light or no ketosis (Keto-Test result $<200$ vs. $\geq 200 \mu \mathrm{mol}$ BHBA/L). Milk fever was first converted to a binomial result (none vs. case of milk fever) for analysis of overall incidence of milk fever. A second analysis (comparing none or mild cases to severe cases) was performed afterward to obtain an estimate of the incidence of severe cases of milk fever.

Gestation length, DIM at first and last breeding, as well as number of breedings per conception were analyzed on pregnant cows only with the MIXED procedure of SAS, with treatment, parity, block, and herd, as well as the treatment $\times$ parity interaction as fixed effects of the model. The LIFETEST procedure of SAS was used to perform survival analysis of pregnant cows. Conception rates at first and second services were compared using the GLIMMIX procedure with the same model as described above. For all analyses, effects were declared significant at $P \leq 0.05$ and as a tendency at $0.05<P \leq 0.10$.

\section{RESULTS AND DISCUSSION}

The main objective of the present experiment was to compare the effects of SDP or CDP management on health and reproduction measures taken on a large number of cows. Given the small herd size in Quebec, where average herd size is 58 cows (Valacta, 2009), several commercial herds were enrolled. Results varied among herds, which will be discussed later, although it was not the main purpose of the study.

Actual days dry were: $34.9 \pm 1.3$ and $60.1 \pm 1.5 \mathrm{~d}$ for primiparous and $40.5 \pm 1.4$ and $70.9 \pm 1.4 \mathrm{~d}$ for multiparous, SDP and CDP cows, respectively. Incidence of twins was similar among treatments $(P=0.45)$ but twice as high in multiparous than primiparous cows (4.9 vs. $2.5 \%$, respectively; $P=0.04$ ).

\section{Culling Rate}

Out of the 850 cows involved in the study, $563(66.2 \%)$ were kept in the herd until the next DP, 33 (3.9\%) died, and $254(29.9 \%)$ were sold. The proportion of cows dead was not different among treatments $(P=0.19)$. However, a significant treatment $\times$ parity interaction for culling rate was observed $(P=0.03)$. No difference
Table 1. Culling reasons and respective proportion of cows (\% of culled cows)

\begin{tabular}{lc}
\hline Item & Proportion \\
\hline Intentional culling & \\
Sold to another producer & 6.9 \\
Poor milk production & 3.8 \\
Poor conformation & 2.8 \\
Unintentional culling & \\
Mastitis/high SCC & 15.7 \\
Reproduction & 13.9 \\
Feet and leg problems & 13.5 \\
Other diseases & 7.9 \\
Injury & 5.7 \\
Death & 3.8 \\
Age & 2.8 \\
Difficult calving & 2.5 \\
Other/unknown & 20.8 \\
\hline
\end{tabular}

existed in culling rate for second-lactation cows $(24.0$ vs. $27.3 \% \pm 3.2$ for CDP and SDP, respectively; $P=$ $0.45)$. However, a significantly higher culling rate occurred in multiparous CDP cows compared with SDP (42.6 vs. $31.6 \% \pm 3.7$ for $\mathrm{CDP}$ and SDP, respectively; $P=0.02)$. These numbers are similar to the actual situation in Quebec, where the average culling rate for all parities was $32.6 \%$ in 2008 (Valacta, 2009). Reasons and respective proportions of culled cows were not different among treatments $(P \geq 0.28$; Table 1$)$.

The proportion of cows culled in the first $30 \mathrm{~d}$ after calving tended to be higher for CDP cows (9.5 vs. $6.2 \%$ for CDP and SDP, respectively; $P=0.07)$. The main reasons for culling during the first 30 DIM were disease (18.2\%), mastitis or high SCC (13.6\%), and difficult calving (12.1\%). Significantly more CDP cows were culled both during the first 60 (14.0 vs. $8.9 \%$ for CDP and SDP, respectively; $P=0.05$ ) and the first $90 \mathrm{DIM}$ (16.7 vs. $10.5 \%$ for $\mathrm{CDP}$ and SDP, respectively; $P=$ $0.008)$. The main reasons for culling during these periods were feet and leg problems, mastitis, and disease.

\section{Metabolic Disorders}

The incidence of ketosis was affected both by parity $(P=0.001)$ and by DP management strategy $(P=$ 0.008; Table 2) when a Keto-Test result at or above 100 $\mu \mathrm{mol}$ of $\mathrm{BHBA} / \mathrm{L}$ was used as threshold level. However, the treatment difference was not significant when the threshold level was set to $200 \mu \mathrm{mol}$ of BHBA/L or above $(P=0.22)$, although incidence remained higher for third- and greater-lactation cows than for second-lactation cows $(P=0.02)$. These results imply that the SDP management decreased the incidence of cases between 100 and $200 \mu \mathrm{mol}$ of BHBA/L, which are often subclinical cases and are, therefore, not treated 
Table 2. Incidence of metabolic disorders according to parity and dry period management strategy

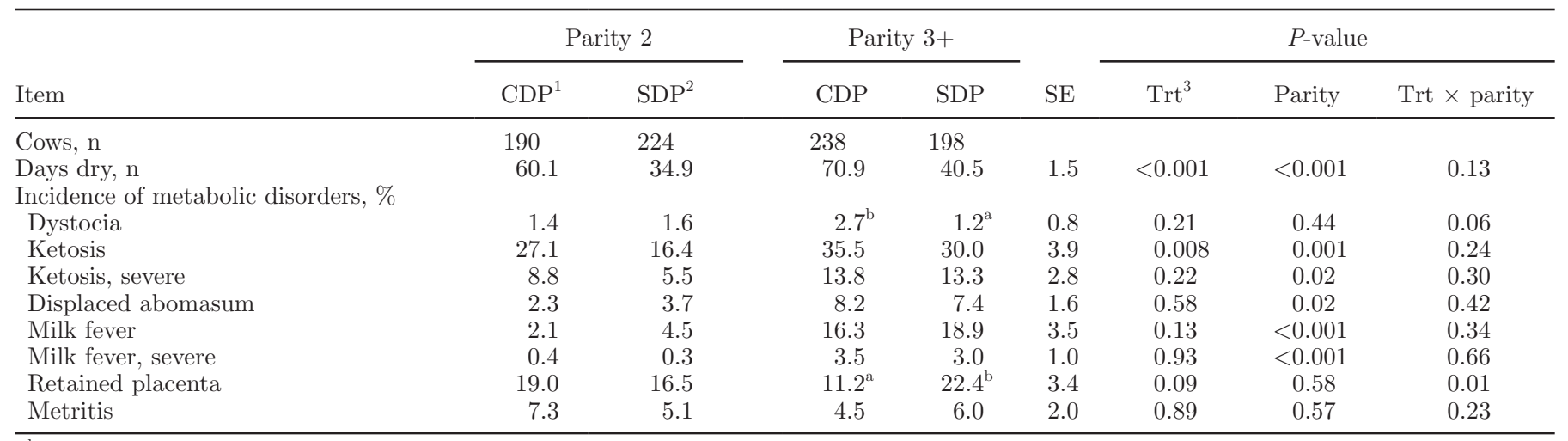

$\overline{\mathrm{a}, \mathrm{b}}$ Means within the same row and parity group and with different superscripts differ; $P \leq 0.05$.

${ }^{1}$ Conventional dry period, $60 \mathrm{~d}$ dry.

${ }^{2}$ Short dry period, $35 \mathrm{~d}$ dry.

${ }^{3}$ Treatment.

by producers. Results were similar among herds; the proportion of cows with ketosis was numerically lower following an SDP in 11 of the 13 herds.

Subclinical ketosis has been associated with increased risks of developing other diseases, decreased milk production and compromised reproductive performance (Reist et al., 2003; Duffield, 2006; Walsh et al., 2007). Greater incidence of subclinical ketosis for CDP cows suggests a greater rate of fat mobilization and perhaps greater negative energy balance. Unfortunately, it was not possible to measure DMI or estimate energy balance in the present study because cows were in commercial herds. However, preliminary results from a study conducted by our team conjointly with the present project revealed that DMI was higher (19.6 vs. $16.9 \pm 0.9 \mathrm{~kg} / \mathrm{d}$; SDP and CDP, respectively) during the first 21 DIM following a short DP (Jolicoeur et al., 2009). Results from this study also indicated lower plasma NEFA and BHBA concentrations for cows assigned to SDP; ketosis incidence was not reported because of the small number of animals $(\mathrm{n}=12)$. Similarly, Watters et al. (2008) reported lower postpartum NEFA concentrations for cows managed with a 34- vs. 55-d DP. In contrast, Rastani et al. (2005) detected no difference in plasma metabolites (NEFA, BHBA, and glucose) between cows assigned to a 28- or a 56-d DP. However, these authors estimated energy balance and noted improved postpartum energy status for cows assigned to the shorter DP. In this last experiment, decreasing the length of the DP decreased milk yield but did not affect SCM production.

The incidence of ketosis reported by Watters et al. (2008) was $18.6 \%$, with no treatment effect. These authors used a combination of several criteria (low milk production, decreased appetite, manure consistency, and detection of acetoacetate in milk) to determine ke- totic cows. Incidences reported by these authors would probably correspond to the cases of severe ketosis in our experiment. The fact that all cows from the present study were systematically tested using the Keto-Test and were then declared ketotic or not, based on the result, probably allows a better uniformity of the definition of ketotic cows.

Incidence of displaced abomasum was higher in older cows $(P=0.02)$ but was not affected by DP management $(P=0.58)$. Watters et al. (2008) reported similar results: 5.5 versus $6.2 \%$ for 55 - and 34 -d DP management, respectively.

Similarly, milk fever incidence was higher in third- or greater-lactation cows $(P<0.001)$. However, treatment did not affect occurrence of either total or severe milk fever cases $(P \geq 0.13)$.

A significant treatment $\times$ parity interaction was noted for incidence of retained placenta $(P=0.01)$. The management strategy used in the DP had no effect on frequency of retained placenta in second-lactation cows $(P=0.52)$ but the incidence was doubled in SDP compared with CDP cows $(P=0.003)$ for third- or greater-lactation cows. The reason for this increase is unknown, but this observation was numerically present in 9 of the 13 herds involved in the study. Although rations fed were different for each herd, ration details obtained from each nutritionist were analyzed; no major nutritional or mineral deficiency or imbalance was observed. Ration details are provided in a companion paper (Santschi et al., 2011a). Several other possible explanations were investigated, namely gestation length, dystocia, and calf size. Gestation length was similar among groups (279.4 vs. $279.1 \pm 0.5 \mathrm{~d}$ for CDP and SDP, respectively; $P=0.74$ ). Regarding dystocia, a tendency for a treatment $\times$ parity interaction existed 
$(P=0.06$; Table 2$)$. No difference existed for secondlactation cows, but older cows assigned to CDP had an increased rate of difficult calvings compared with SDP cows $(P=0.04)$. This result indicates that occurrence of dystocia was decreased for multiparous SDP cows, which was the group of cows with highest retained placenta incidence. Difficult calving is, therefore, not the explanation for the increased incidence of this disorder. Concerning calf size, because calves could not be weighed in a comparable way in all herds, classification as small, medium, or large was used as estimation. Classification was made by the producer, comparing calves from his own herd. Respective proportions were not affected by DP management (average: $14.1 \%$ small; $58.6 \%$ medium; $27.3 \%$ large; $P=0.85$ ).

Failure of placental detachment has also been associated with failure of the immune system to successfully degrade the placentomes at the end of pregnancy (LeBlanc, 2008), which was further associated with cows in severe negative energy balance. This period of severe energy deficit impairs immune function, which, in turn, increases risks of retained placenta (Goff and Horst, 1997). However, in the present study, cows with increased incidence of retained placenta actually had lower incidence of ketosis. Furthermore, retained placenta is known to be an important predisposing factor for uterine infections, namely metritis (LeBlanc, 2008; Sheldon et al., 2008; Könyves et al., 2009). In the present study, the incidence of metritis was not affected by treatment and parity $(P \geq 0.57)$.

Pezeshki et al. $(2007,2008)$ and Watters et al. (2008) reported no differences in the incidence of metabolic disorders for traditional versus short DP. The number of cows (total of 61, assigned to 2 treatments) involved in the study by Pezeshki et al. (2008) did not allow enough statistical power to detect differences. On the other hand, Watters et al. (2008) had close to 200 cows per parity and treatment group, similar to the present experiment. The incidence of retained placenta was much higher in the present study than that reported by Watters et al. (2008), where incidence was 8.9 to $9.5 \%$, using a similar definition for the disease as that in the present paper. However, these authors reported metritis incidences of 15.6 to $19.6 \%$, which are much higher than the present experiment. In their case, metritis was diagnosed between 4 and $15 \mathrm{~d}$ postpartum and defined as inflammation of the lining of the uterus identified by vaginal examination and the presence of abnormal discharge. The difference in definition used might explain the higher metritis incidence rate in the study of Watters et al. (2008).

\section{Mastitis}

The overall proportion of cows with mastitis was higher in multiparous than primiparous cows $(P=$ 0.02 ; Table 3), which has been reported previously (Green et al., 2007) but no effect of DP management on overall incidence of mastitis was observed $(P=0.94)$. Mastitis cases were recorded throughout the project and grouped according to time relative to calving. The treatment had no effect on occurrence at either dry-off or in the first months postpartum $(P \geq 0.60)$. RajalaSchultz et al. (2005) have demonstrated that higher milk production at dry-off was a significant risk factor for environmental IMI at calving; above $12.5 \mathrm{~kg} / \mathrm{d}$ at dry-off, each additional $5 \mathrm{~kg}$ of milk produced increased the odds of a new IMI by $77 \%$. Actual milk yields at dry-off in the present study averaged $19.3 \pm 0.6$ and $18.4 \pm 0.6 \mathrm{~kg}$ for CDP and SDP cows, respectively (estimated values). Although lower milk yield at dry-off was expected for SDP cows because of the extended milking period, the high persistency of cows in the present study prevented a significant decrease in yield. Accordingly, incidence of mastitis was not influenced by DP management. Although incidence rates differed among herds, treatment effect remained nonsignificant.

Subclinical mastitis is generally described as a SCC at or above 200,000 cells $/ \mathrm{mL}$ of milk (Schepers et al., 1997). It was, therefore, investigated whether the DP

Table 3. Incidence of clinical mastitis during specific periods relative to calving according to parity and dry period management strategy

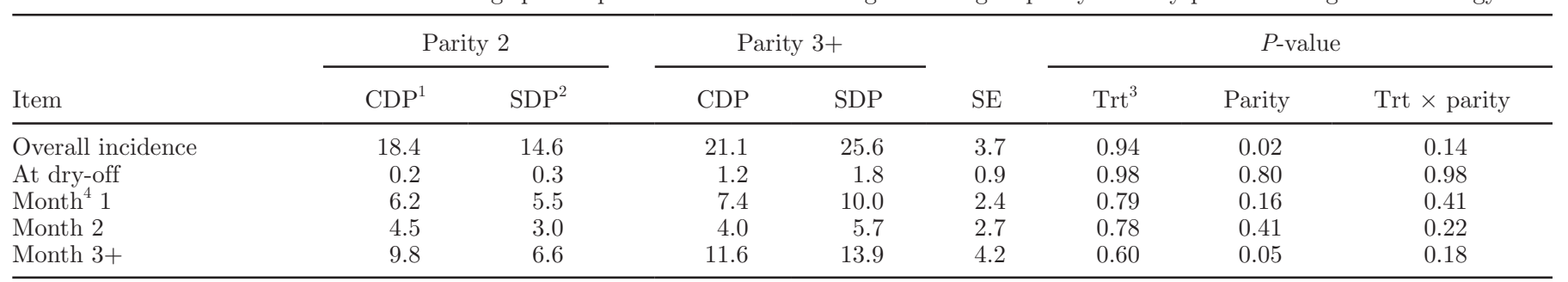

${ }^{1}$ Conventional dry period, $60 \mathrm{~d}$ dry.

${ }^{2}$ Short dry period, 35 d dry.

${ }^{3}$ Treatment.

${ }^{4}$ Month of lactation. 
management strategy used influenced the proportion of cows with SCC at or above 200,000 cells $/ \mathrm{mL}$ on the first test day of the new lactation. The average incidence of subclinical mastitis was not influenced by treatment $(P=0.29)$ but was significantly higher in multiparous than primiparous cows $(P=0.02)$. Incidences were 12.4 and $11.4 \%$ for second-lactation cows and 21.7 and $16.4 \%$ for third- or greater-lactation cows, CDP and SDP, respectively. In a retrospective analysis, Kuhn et al. (2006) concluded that DP shorter than $60 \mathrm{~d}$ increased the SCC in the following lactation. Although retrospective studies use an important number of animals, management and health information on the cows involved is missing. In contrast, results from planned experiments suggest no effect of DP management strategy on incidence of mastitis and differences in SCC (Gulay et al., 2003; Church et al., 2008; Watters et al., 2008), as also observed in the present study.

As mentioned previously, all producers involved in the present study systematically used dry cow antibiotic treatments at dry-off. Our results suggest that under these conditions, shortening the DP does not influence the risk of mastitis either at dry-off or during the subsequent lactation.

\section{Reproduction}

As discussed earlier, gestation length was not affected by DP management strategy $(P=0.74$; Table 4$)$. This observation had also been reported by others (Gümen et al., 2005; Watters et al., 2009), confirming that a modification in the DP length and management does not affect parturition date.

No effect of treatment or parity was noted on DIM at first breeding, number of breedings per conception, or days open during the following lactation $(P \geq 0.18$;
Table 4), which is similar to results from Gümen et al. (2005). Watters et al. (2009) have reported a decrease in DIM at first ovulation following a shorter DP. Their results indicated that a shorter DP management resulted in less than half as many anovular cows by 70 DIM ( 8 vs. 18\%). These authors used 781 cows from a single herd, which allowed precise monitoring of the reproductive cycles of each cow through palpation, blood progesterone concentrations, and a uniform reproductive management protocol. The design of the present study did not allow recording of ovulations in all herds.

Watters et al. (2009) emphasized that one of the most important observations from their study was the tendency for a decrease in days to pregnancy following a shorter DP for multiparous cows. This effect was not significant in the present experiment $(P=0.18)$, although a numerical decrease in days open was observed for both parity groups following a short DP (Table 4). Although this was not the purpose of the present study, the design used in this trial allowed an insight into variation among herds. Results of DP management on days open among the different herds are shown in Figure 1. Shortening the DP resulted in a numerical decrease in days to pregnancy in most herds. However, one herd clearly stands out and shows opposite results to the 12 others. Removing this herd from the analysis yields a tendency for fewer days open and for a better conception rate at second service for cows assigned to SDP $(P \leq 0.09)$. The reason for this opposite response is not known. Gümen et al. (2005) and Watters et al. (2009), respectively, reported a decrease of 24 and 20 d open for third- or greater-lactation cows following a shortened DP of 28 and $35 \mathrm{~d}$. In contrast, Pezeshki et al. (2008) observed no difference in days open for cows with a 49 or $28 \mathrm{~d}$ DP, although days open averaged 85 $\mathrm{d}$ in their experiment, which is much lower than in the

Table 4. Reproductive measures according to parity and dry period management strategy

\begin{tabular}{|c|c|c|c|c|c|c|c|c|}
\hline \multirow[b]{2}{*}{ Item } & \multicolumn{2}{|c|}{ Parity 2} & \multicolumn{2}{|c|}{ Parity $3+$} & \multirow[b]{2}{*}{ SE } & \multicolumn{3}{|c|}{$P$-value } \\
\hline & $\mathrm{CDP}^{1}$ & $\mathrm{SDP}^{2}$ & CDP & SDP & & $\operatorname{Trt}^{3}$ & Parity & Trt $\times$ parity \\
\hline Gestation length, ${ }^{4} \mathrm{~d}$ & 279.1 & 278.8 & 279.5 & 279.4 & 0.5 & 0.74 & 0.29 & 0.72 \\
\hline DIM first breeding & 81.1 & 81.0 & 82.0 & 82.1 & 2.0 & 0.98 & 0.61 & 0.96 \\
\hline Breedings/conception & 2.5 & 2.5 & 2.7 & 2.5 & 0.2 & 0.46 & 0.45 & 0.54 \\
\hline First-service CR, ${ }^{5} \%$ & 39.3 & 36.7 & 36.5 & 34.7 & 4.2 & 0.56 & 0.56 & 0.92 \\
\hline Second-service CR, ${ }^{6} \%$ & 32.7 & 41.8 & 34.5 & 41.2 & 5.5 & 0.11 & 0.90 & 0.81 \\
\hline First + second CR, \% & 61.1 & 64.0 & 59.0 & 62.8 & 4.3 & 0.39 & 0.69 & 0.92 \\
\hline Pregnant at 150 DIM, \% & 71.8 & 70.3 & 66.5 & 68.9 & 4.1 & 0.90 & 0.40 & 0.59 \\
\hline Days open, $\mathrm{n}$ & 140.3 & 131.0 & 143.3 & 134.4 & 7.4 & 0.18 & 0.66 & 0.97 \\
\hline
\end{tabular}

${ }^{1}$ Conventional dry period, $60 \mathrm{~d}$ dry.

${ }^{2}$ Short dry period, 35 d dry.

${ }^{3}$ Treatment.

${ }^{4}$ For the previous gestation, calculated as the time interval between conception and calving.

${ }^{5}$ Conception rate.

${ }^{6}$ Expressed as percentage of cows conceiving at second service over total number of cows not pregnant after first service. 


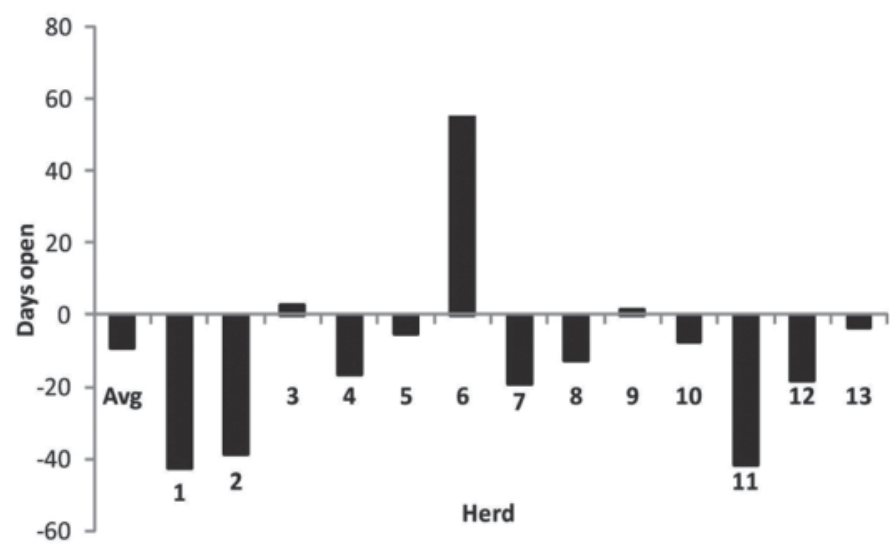

Figure 1. Variation in days open on average and among the 13 herds involved in the study. Bars represent the difference in days open following a short (35-d) or conventional (60-d) dry period management strategy. Respective number of cows involved in the study per herd was $1=83 ; 2=54 ; 3=84 ; 4=73 ; 5=159 ; 6=54 ; 7=63 ; 8=38$; $9=54 ; 10=50 ; 11=53 ; 12=34 ; 13=51$.

present study. Average days open measured in the present experiment are similar to the average in Quebec, which was $145 \mathrm{~d}$ in 2008 (Valacta, 2009).

The analysis of the proportion of cows pregnant with regard to DIM as a survival curve allows including culled cows in the data set and, therefore, accounting for cows that leave the herd (Figure 2). Cumulative pregnancy rate is the best metric for evaluating reproduction, as it allows reflecting the effect of reproduction failure as well as the actual fertility of cows that conceived. According to LeBlanc (2010), pregnancy rate is the best available single measure of overall reproductive performance at the herd level, which measures the probability that open cows become pregnant per unit of time. In the present case, pregnancy rate was not affected by DP management strategy $(P \geq 0.38)$.

As reviewed by Butler (2005), previous studies have demonstrated that negative energy balance delays recovery of postpartum reproductive functions, mainly by influencing the resumption of ovulatory cycles. Early resumption of cycles is important because conception rates increase with successive cycles. Results from Watters et al. $(2008,2009)$ demonstrated that reproduction was improved following a shorter DP. In the present study, although ketosis results suggest that cows on SDP were in less negative energy balance, no significant effect was observed on reproductive performance. However, it was not possible to evaluate time at which ovulatory cycles resumed.

\section{CONCLUSIONS}

The present experiment is the only recent study looking at effects of shorter DP on health and reproduc- tion on a large number of cows in several commercial herds. Our results demonstrate that the incidence of ketosis, especially mild ketosis, is decreased by the SDP management. Although multiparous CDP cows had increased occurrence of dystocia, the incidence of retained placenta was increased in multiparous cows assigned to SDP. The reason for this increase is unclear. The DP management strategy used had no effect on other health problems: displaced abomasum, milk fever, metritis, and mastitis, but decreased the culling rate in mature cows. The results of reproductive measures show no effect of DP management on the number of breedings, conception rates, days open, and proportion of cows pregnant at 150 DIM. The results from the present study vary among herds, indicating that management practices in the individual herds influence the response to shorter DP management. Further studies involving a greater number of commercial herds
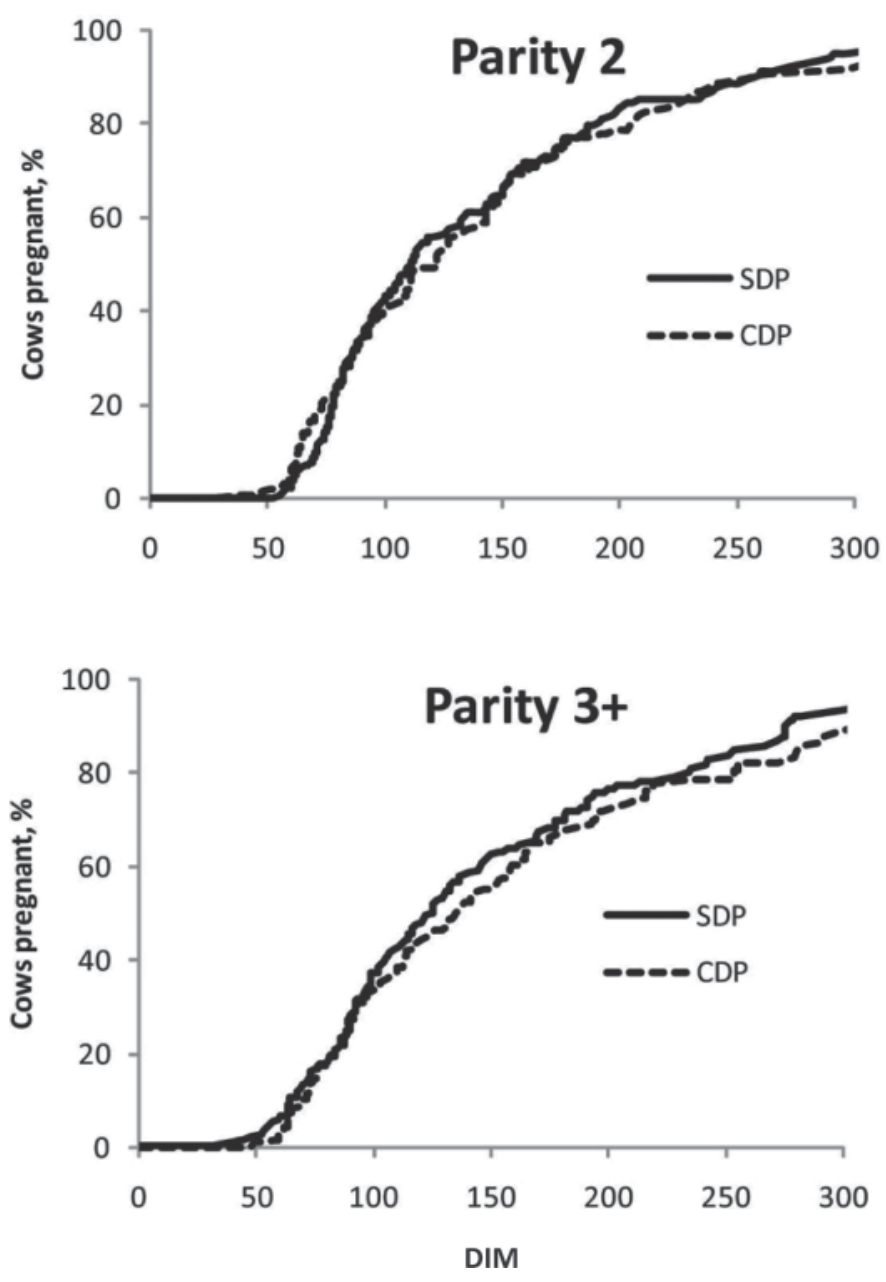

Figure 2. Survival curve for days to pregnancy for cows assigned to a short (SDP; 35-d) or conventional (CDP; 60-d) dry period management strategy according to parity. Parity 2: $P=0.71$; Parity $3+$ : $P=0.38$. 
are needed to clearly understand this variation among herds and identify factors on which the producer could rely to select the best DP management according to the cows to dry-off.

\section{ACKNOWLEDGMENTS}

The authors acknowledge the help of the producers, veterinarians, and nutritionists involved in this study for their participation and implication. Thanks to Jean Baril and the Canadian division of Elanco Animal Health (Guelph, Ontario, Canada) for generously providing the Keto-Tests. This project was financed by the Action concertée Novalait-FQRNT-MAPAQ-AAC (Quebec, QC, Canada).

\section{REFERENCES}

Bachman, K. C., and M. L. Schairer. 2003. Invited review: Bovine studies on optimal lengths of dry periods. J. Dairy Sci. 86:30273037.

Butler, W. R. 2003. Energy balance relationships with follicular development, ovulation and fertility in postpartum dairy cows. Livest. Prod. Sci. 83:211-218.

Butler, W. R. 2005. Relationships of negative energy balance with fertility. Adv. Dairy Technol. 17:35-46.

Church, G. T., L. K. Fox, C. T. Gaskins, D. D. Hancock, and J. M. Gay. 2008. The effect of a shortened dry period on intramammary infections during the subsequent lactation. J. Dairy Sci. 91:4219-4225

Coppock, C. E., R. W. Everett, R. P. Natzke, and H. R. Ainslie. 1974 Effect of dry period length on Holstein milk production and selected disorders at parturition. J. Dairy Sci. 57:712-718.

de Feu, M. A., A. C. O. Evans, P. Lonergan, and S. T. Butler. 2009. The effect of dry period duration and dietary energy density on milk production, bioenergetic status, and postpartum ovarian function in Holstein-Friesian dairy cows. J. Dairy Sci. 92:6011-6022.

Duffield, T. F. 2006. Minimizing subclinical metabolic diseases in dairy cows. Adv. Dairy Technol. 18:43-55.

Goff, J. P., and R. L. Horst. 1997. Physiological changes at parturition and their relationship to metabolic disorders. J. Dairy Sci. 80:1260-1268

Green, M. J., A. J. Bradley, G. F. Medley, and W. J. Browne. 2007. Cow, farm, and management factors during the dry period that determine the rate of clinical mastitis after calving. J. Dairy Sci. 90:3764-3776

Grummer, R. R., D. G. Mashek, and A. Hayirli. 2004. Dry matter intake and energy balance in the transition period. Vet. Clin. North Am. Food Anim. Pract. 20:447-470.

Gulay, M. S., M. J. Hayen, K. C. Bachman, T. Belloso, M. Liboni, and H. H. Head. 2003. Milk production and feed intake of Holstein cows given short (30-d) or normal (60-d) dry periods. J. Dairy Sci. 86:2030-2038.

Gümen, A., R. R. Rastani, R. R. Grummer, and M. C. Wiltbank 2005. Reduced dry periods and varying prepartum diets alter postpartum ovulation and reproductive measures. J. Dairy Sci. 88:2401-2411

Jamrozik, J., J. Fatehi, G. J. Kistemaker, and L. R. Schaeffer. 2005. Estimates of genetic parameters for Canadian Holstein female reproduction traits. J. Dairy Sci. 88:2199-2208.

Jolicoeur, M. S., A. F. Brito, D. Pellerin, D. Lefebvre, R. Berthiaume, and C. L. Girard. 2009. Short dry period management improves peripartum ruminal adaptation in dairy cows. J. Dairy Sci. 92(Suppl. 1):333.

Klusmeyer, T. H., A. C. Fitzgerald, A. C. Fabellar, J. M. Ballam, R. A. Cady, and J. L. Vicini. 2009. Effect of recombinant bovine so- matotropin and a shortened or no dry period on the performance of lactating dairy cows. J. Dairy Sci. 92:5503-5511.

Könyves, L., O. Szenci, V. Jurkovich, L. Tegzes, A. Tirián, N. Solymosi, G. Gyulay, and E. Brydl. 2009. Risk assessment of postpartum uterine disease and consequences of puerperal metritis for subsequent metabolic status, reproduction and milk yield in dairy cows. Acta Vet. Hung. 57:155-169.

Kuhn, M. T., J. L. Hutchison, and H. D. Norman. 2006. Effects of length of dry period on yields of milk fat and protein, fertility and milk somatic cell score in the subsequent lactation of dairy cows. J. Dairy Res. 73:154-162.

LeBlanc, S. J. 2008. Postpartum uterine disease and dairy herd reproductive performance: A review. Vet. J. 176:102-114.

LeBlanc, S. 2010. Assessing the association of the level of milk production with reproductive performance in dairy cattle. J. Reprod. Dev. 56:S1-S7.

Mee, J. F. 2008. Prevalence and risk factors for dystocia in dairy cattle: A review. Vet. J. 176:93-101.

Pezeshki, A., J. Mehrzad, G. R. Ghorbani, B. De Spiegeleer, R. J. Collier, and C. Burvenich. 2008. The effect of dry period length reduction to 28 days in the performance of multiparous dairy cows in the subsequent lactation. Can. J. Anim. Sci. 88:449-456.

Pezeshki, A., J. Mehrzad, G. R. Ghorbani, H. R. Rahmani, R. J. Collier, and C. Burvenich. 2007. Effects of short dry periods on performance and metabolic status in Holstein dairy cows. J. Dairy Sci. 90:5531-5541

Rajala-Schultz, P. J., J. S. Hogan, and K. L. Smith. 2005. Short communication: Association between milk yield at dry-off and probability of intramammary infections at calving. J. Dairy Sci. 88:577-579.

Rastani, R. R., R. R. Grummer, S. J. Bertics, A. Gümen, M. C. Wiltbank, D. G. Mashek, and M. C. Schwab. 2005. Reducing dry period length to simplify feeding transition cows: milk production, energy balance, and metabolic profiles. J. Dairy Sci. 88:1004-1014.

Reist, M., D. K. Erdin, D. von Euw, K. M. Tschümperlin, H. Leuenberger, H. M. Hammon, C. Morel, C. Philipona, Y. Zbinden, N. Künzi, and J. W. Blum. 2003. Postpartum reproductive function: Association with energy, metabolic and endocrine status in high yielding dairy cows. Theriogenology 59:1707-1723.

Santschi, D. E., D. M. Lefebvre, R. I. Cue, C. L. Girard, and D. Pellerin. 2011a. Complete-lactation milk and component yields of cows assigned to a short (35-d) or conventional (60-d) dry period management in commercial Holstein herds. J. Dairy Sci. 94:23022311

Santschi, D. E., D. M. Lefebvre, R. I. Cue, C. L. Girard, and D. Pellerin. 2011b. Economic impact of a short (35-d) compared to a conventional (60-d) dry period management in commercial Canadian Holstein herds. J. Dairy Sci. doi:10.3168/jds.2010-3596.

SAS Institute. 1999. User's Guide: Statistics. Version 8. SAS Institute, Cary, NC

Schepers, A. J., T. J. Lam, Y. H. Schukken, J. B. Wilmink, and W. J. Hanekamp. 1997. Estimation of variance components for somatic cell counts to determine thresholds for uninfected quarters. J. Dairy Sci. 80:1833-1840.

Sheldon, I. M., E. J. Williams, A. N. A. Miller, D. M. Nash, and S. Herath. 2008. Uterine diseases in cattle after parturition. Vet. J. 176:115-121.

Valacta. 2009. Évolution de la production laitière québécoise 2008 Pages 33-62 in Le Producteur de Lait Québécois. Numéro spécial

Walsh, R. B., J. S. Walton, D. F. Kelton, S. J. LeBlanc, K. E. Leslie, and T. F. Duffield. 2007. The effect of subclinical ketosis in early lactation on reproductive performance of postpartum dairy cows. J. Dairy Sci. 90:2788-2796.

Watters, R. D., J. N. Guenther, A. E. Brickner, R. R. Rastani, P. M. Crump, P. W. Clark, and R. R. Grummer. 2008. Effects of dry period length on milk production and health of dairy cattle. J. Dairy Sci. 91:2595-2603.

Watters, R. D., M. C. Wiltbank, J. N. Guenther, A. E. Brickner, R. R. Rastani, P. M. Fricke, and R. R. Grummer. 2009. Effect of dry period length on reproduction during the subsequent lactation. J. Dairy Sci. 92:3081-3090. 